\title{
An Analysis Study of the Feasibility on Offering Bachelor's Degree in Service Science
}

\author{
Amer Al-Badarneh ${ }^{1 *}$, James Spohrer ${ }^{2}$, Basheer Al-Duwairi ${ }^{1}$, Mohammed Shatnawi ${ }^{1}$ \\ 1 Jordan University of Science and Technology, Irbid, JORDAN \\ ${ }^{2}$ IBM Almaden Research Center, San Jose, CA, USA
}

Received 22 June 2017 - Revised 21 February 2018 - Accepted 21 February 2018

\begin{abstract}
The service sector is the uppermost growing stake of the developed economies. The reliance of this sector on information technology (IT) deserves revision of IT curricula. As the field of computing continues to grow and diversify, and new computing-related disciplines emerge, existing curriculum programs must be updated regularly and new computing disciplines will be drafted. The primary aims of this paper, therefore, are firstly, to introduce the emerging academic discipline known as Service Science, Management, and Engineering (SSME), in response to the growing dominance of the service sector in emerging economies. Secondly, we present a feasibility study of establishing a new undergraduate academic program that offers a Bachelor's degree in SSME. The study was based on analyzing the results of a study conducted to evaluate the workforce in Jordanian information and communications industry. The results of the study concluded that the demand for hybrid IT graduates in the knowledge-based service economy is rapidly growing.
\end{abstract}

Keywords: bachelor's degree, curriculum development, feasibility study, service science, SSME

\section{INTRODUCTION}

Recently, there is an increase interest to upgrade academic programs by new disciplines. In today's knowledgeintensive economy, services represent the fastest growing portion of the world economy and the service sector has grown to a degree that it is ranked first in terms of gross domestic product as well as number of workers in all major industrialized countries (Spohrer \& Maglio, 2008; Solnet, 2012). Recently, there is a "call to action" focusing educational institutes to update academic curriculum in areas related to the dominant sector of economics activity (Al-Badarneh, Spohrer, \& Al-Duwairi, 2013; Chesbrough, 2004). Services contribute more than 50\% of World GDP economy (Soubbotina \& Katherine, 2000) and service innovation represents the main factor for revenue and profit growth.

Service science is an emerging multidisciplinary approach to study value-cocreation phenomena. It is the study of complex systems that allow us to create a better world, in which various types of service system entities (e.g., people, businesses, universities, and technologies) take actions that provide value for others. Now, service science has led hundreds of organizations and thousands of people into a remarkable preliminary investment prioritization by creating service innovation roadmaps (Spohrer \& Maglio, 2010).

In the report published by the U.S. Department of Labor (Bureau of Labor Statistics, 2016) which introduces the employment figures in the United States, it shows the increase demand for the employment of people with hybrid (mixed) experience of technical and business skills (T-Shaped professionals) instead of traditional IT jobs (Beblavý, Fabo, \& Lenearts, 2016; Thompson, Bellanca, Owens, \& Lorenzo, 2012).

In line with this demand on service scientists locally and globally, we believe, Jordan in general and the University of Science and Technology (JUST) in particular, there is a need to take appropriate initiatives and

(C) 2018 by the authors; licensee Modestum Ltd., UK. This article is an open access article distributed under the terms and conditions of the Creative Commons Attribution License (http://creativecommons.org/licenses/by/4.0/).

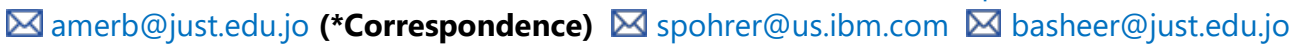

mshatnawi@just.edu.jo 


\section{Contribution of this paper to the literature}

- To take appropriate initiatives and rehabilitation of graduates and provide them with the knowledge and skills necessary to compete better in the job market.

- To develop a competent academic program that is systematically developed and reviewed to ensure that it continues to meet the needs of the fast-growing and evolving IT service-based sector.

- To present a feasibility study to illustrate the importance, rationale, and objectives of initiating a new service science undergraduate program at Jordan University of Science and Technology.

rehabilitation of graduates and provide them with the knowledge and skills necessary to compete better in the job market locally, regionally and globally. The purpose of this study is to present a feasibility study to illustrate the importance, rationale, and objectives of initiating a new undergraduate SSME program within the college of Computer \& Information Technology (CIT) at JUST.

This study aims to be a catalyst for developing competent academic program of high quality that is systematically developed and reviewed to ensure that it continues to meet the needs of the fast-growing and evolving IT service-based sector in Jordan and in the region. This work was conducted based on two main activities, which are: (1) Reviewing existing SSME programs locally, regionally, and internationally to have a clear perception of others' experiences in offering programs in service science. This includes the academic as well as the organizational aspects of the existing program. (2) Analyzing the results of a study conducted by Ministry of Information and Communications Technology (ICT) of Jordan entitled "Workforce in Jordanian ICT Industry: Evaluation and Needs Assessment 2010" (Ministry of Information and Communications Technology [MoICT], 2010).

\section{BACKGROUND}

\section{Overview of SSME}

Service Science, Management, and Engineering (SSME) is a term introduced recently by IBM, highlighting the need for a multidisciplinary approach to service innovation (Spohrer \& Kwan, 2009). SSME is a multi-disciplinary program to the study, design, and implementation of services systems. It combines studies in disparate fields such as computer science, management, engineering, and business strategies. In these complex systems, people and technology are arranged and interact in harmony to provide value for others. In general, SSME academic curriculum should consist of three parts (Spohrer, Maglio, Bailey, \& Gruhl, 2007): science, management, and engineering. Science is a way to create knowledge to: (i) understand services and their evolution, (ii) provide tools and methods to study services, and (iii) develop solutions to challenging problems. Management covers investment approaches to improve service systems; it also improves the process of creating and capturing value. Engineering is how to invent new technologies that improve the scaling of service systems; it is a way to apply knowledge and create new value.

\section{SSME in Academia}

SSME is beginning to emerge in academia and it is gaining high importance and attracting the attention of leading university researchers, teaching faculty, industry people, and government officials. In fact, it is becoming a common target of many schools and universities worldwide (especially in USA and Europe). Several top U.S. and top international universities are formulating and offering professional Masters-level concentrations or degree programs containing courses related to this field.

For example, over two hundred universities in fifty countries have begun service-related academic programs, service science textbooks, books, and readings have been published worldwide (e.g., Service Is Front Stage (Teboul, 2006), Service Science: Research and Innovations in the Service Economy (Hefley, \& Murphy, 2008), and Service Management (Fitzsimmons, Fitzsimmons, \& Bordoloi, 2014)). Furthermore, there is an increasing number of related activities including, first, emerging professional associations such as International Society of Service Innovation Professionals - issip.org, second, establishing special interest groups (SIG) in service science such as Institute for Operations Research and the Management Sciences - INFORMS, finally, launching and expanding several annual conferences such as Exploring Service Science and Frontiers in Service. 


\section{THEORETICAL FRAMEWORK}

\section{Justification of Establishing SSME Program}

In today's knowledge-intensive economy, it is very important that companies, governments, and universities are involved in service innovation, because GDP growth of nations, revenue, and profit growth increasingly depends on it (Daniels, 2012; Witell et al. 2016). Academia, in its turn, need to adopt and embrace services as a new discipline through adapting existing curricula and the offering of new dedicated degrees in service innovation. Furthermore, people in the academic field need to play an active and productive role in initiating frontier research in service innovation in partnership with businesses for the good of society.

Here in Jordan in general and at JUST in particular, it is in our best interest to understand, leverage, and adapt to the increasing importance of services in several business sectors. It is not only the importance of services itself, but also it is vital to focus on this field of study and to adopt it as a new discipline. This comes inline with the strategic objectives of Jordan's ICT sector (MoICT, 2013) that include:

- Promote the role of IT as a service and its potential to transform businesses to become more efficient, productive as well as improve product quality.

- Help Jordanian companies to increase their outreach in the service sector by leveraging novel Internet-based service delivery models.

- Development of applications and solutions targeted toward niche markets including healthcare, banking and gaming industry.

- Leverage Internet-based services in the educational process.

- Better align Universities outcome to industry needs by teaching students necessary and desirable skills.

Also, the research and development strategy for the ICT sector in Jordan (MoICT, 2017) pointed out a userdriven strategy for ICT sector development. Such user-driven strategy promotes software as a product and a service, which is vital for a vibrant and sustainable ICT sector. In this section, the justifications to establish the SSME academic program are presented and discussed.

\section{The Role of SSME Program}

In Jordan, services are the largest share in IT expenditure. The 2016 ICT and IT Enabled Services (ITES) Sector Classification and Statistics Survey (MoICT, 2016) recognizes IT role beyond the supply of computer hardware and software. IT plays an increasing role in the provisioning of services over communications networks, such as the provisioning of information, applications and transaction services. Government policy on ICT also encourages companies, both within and outside of Jordan, to make online services and applications available in the Jordanian market. The following points discuss the important role that SSME will play in Jordan in general and at JUST in particular:

- The service sector has been consistently gaining a bigger portion of the total GDP of the world's biggest economies, the Jordanian economy is no exception to this phenomena. According to a study by the CIAworld Fact Book, the service sector in Jordan is the largest contributor to the Jordanian GDP with a percentage of 66.5 leaving the industrial sector and agricultural sector with only 29.9 percent and 3.7 percent, respectively. In response to this local as well as global demand we believe that Jordan University of Science and Technology (JUST) need to take the appropriate initiatives and qualify our graduates with necessary knowledge and skills to better compete in the local, regional, as well as global job market.

- At JUST, we believe that we should take a leading step and offer a dedicated SSME degree. SSME degree holders will be better aligned with the industry and job market trends. Almost all of the big players in the IT field are moving toward service-oriented and Software as a Service (SaaS) architectures including IBM, Microsoft, Google, HP, Oracle, and many others. In this architecture, every aspect of IT is being offered as a service for a fee beginning with the hardware and ending with application logic. Hardware is being offered as virtual machines (cloud computing), storage, office tools, DBMSs, operating systems and others.

- The SSME department will be the host of exceptional inter-disciplinary faculty members who are capable of conducting cutting-edge research for the benefit of the local and regional service sector. Such research will tackle all sorts of real-life problems facing the service sector. The results of such research will improve our fundamental understanding, engineering, as well as management of the local and regional service sectors.

- The SSME department will outreach to the less-developed local businesses and acquaint them with the global services trend. Furthermore, the department will help them in the transition from product-oriented businesses to service-oriented businesses. 


\section{STUDY APPROACH}

This descriptive study utilized survey research conducted by Ministry of ICT/Jordan (MoICT, 2010). To collect the data needed for this study, a structured questionnaire is utilized and distributed over a representative sample of 111 Jordanian IT companies. The majority of companies $(72 \%)$ are primarily oriented toward information technology activities whereas the remaining focus on telecommunications sector. The response rate $(68 \%)$ was a good proportion representing the total companies answered the questionnaire.

A weighting variable was created to take into account the selection probability and non-responses. With the above number of completions, the sampling error was calculated to be $+/-2$ percentage points.

The objective of this study was to provide an incentive for the development of high quality vocational education with regularly reviewed and systematically developed curricula to ensure that the requirements of the rapidly growing ICT sector in Jordan and the region are met. The results of the study will help:

- The development of specialized academic programs in the field of technology education to meet the needs of industries and rapidly changing requirements

- Establishing high-quality professional education motivated by continuously and systematically reviewed and developed curricula.

- Aligning learning outcomes with required skills by developing training programs and workplaces.

- Enhancing partnerships and collaboration between ICT industry and academic communities.

- Implementing student-centered teaching practices to equip university graduates with appropriate skills and knowledge.

\section{RESULTS \& DISCUSSION}

In the following subsections, we present the analysis results for the needed job and technologies.

\section{Job Roles Importance}

In the survey, companies were asked to evaluate 16 major ICT job roles using scale (1-4) in terms of existing skills, current and future relevance, and proficiency level for both current employees and new graduates. Companies were also inquired about their plans to employ new graduates for certain job roles, their plans to train them, and the availability of the training budget.

The results of the survey showed that the most important job role is the Application Developer, with $57 \%$ of the companies indicated that this role is of high importance now and in the future. Similarly, the job role of the Project Manager is also important now and in the future to $49 \%$ of the companies. The role of the Database Administrator is the third and most important job role, followed by Network Service Specialist, Security Services Specialist, and System Administrator with an assessment rate of $41 \%$ and $36 \%$ of companies, respectively. The lowest percentage in this category was for a Packaged Application Specialist at 19\% of companies. On the other hand, results showed that the most important role now and in the future is the Storage Services Specialist followed by Content Management Specialist and Packaged Applications Specialist.

Regarding the job roles that are considered to be of current and future importance; Testing Specialist took first place with $28 \%$ of respondents, while $11 \%$ of respondents said it was of low current importance but expected to be of high importance in the future. The second place was for both Business Analysts and Integration Specialist. However, $19 \%$ of companies noted that the role of Business Analyst is of low importance at present but is expected to be high in the future followed by Integration Specialist with 15\% of companies. Table 1 shows the average importance (current and future) of all identified job roles. Table 2 presents statistic summaries (mean, standard deviation, median, skewness, Kurtosis, and standard error) of current and future importance of job roles. 
Table 1. Current and future importance of job roles (\%)

\begin{tabular}{|c|c|c|c|c|c|}
\hline Job Role & $\begin{array}{l}\text { LOW current } \\
\text { Importance and } \\
\text { LOW future } \\
\text { Importance } \\
\text { (1) }\end{array}$ & $\begin{array}{l}\text { LOW current } \\
\text { Importance and } \\
\text { future HIGH } \\
\text { Importance } \\
\text { (2) }\end{array}$ & $\begin{array}{l}\text { Moderate Current } \\
\text { Importance and } \\
\text { future Importance } \\
\text { (3) }\end{array}$ & $\begin{array}{l}\text { Current HIGH } \\
\text { Importance and } \\
\text { future HIGH } \\
\text { Importance } \\
\text { (4) }\end{array}$ & No Answer \\
\hline Portals \& Collaboration & 23 & 15 & 20 & 23 & 19 \\
\hline Packaged Application Specialist & 27 & 13 & 20 & 19 & 21 \\
\hline Content Manager Specialist & 27 & 19 & 13 & 28 & 13 \\
\hline Project Manager & 7 & 11 & 25 & 49 & 8 \\
\hline Storage Services Specialist & 31 & 15 & 12 & 20 & 22 \\
\hline Systems Programmer & 12 & 24 & 16 & 36 & 12 \\
\hline Server Services Specialist & 17 & 11 & 19 & 33 & 20 \\
\hline Security Services Specialist & 19 & 13 & 15 & 36 & 17 \\
\hline Network Services Specialist & 17 & 15 & 17 & 36 & 15 \\
\hline Infrastructure Specialist & 21 & 16 & 12 & 35 & 16 \\
\hline Database Administrator & 12 & 15 & 21 & 41 & 11 \\
\hline Test Specialist & 16 & 11 & 28 & 31 & 14 \\
\hline Data Specialist & 20 & 15 & 21 & 24 & 20 \\
\hline Integration Specialist & 20 & 15 & 27 & 20 & 18 \\
\hline Application Developer & 9 & 11 & 15 & 57 & 8 \\
\hline Business Analyst & 11 & 19 & 27 & 32 & 11 \\
\hline
\end{tabular}

Table 2. Statistic summaries of current and future importance of job roles

\begin{tabular}{lcccccc}
\hline Job Role & Mean & S Dev. & Median & Skewness & Kurtosis & S Error \\
\hline Portals \& Collaboration & 2.53 & 1.18 & 2.63 & -0.07 & -1.52 & 0.13 \\
\hline Packaged Application Specialist & 2.39 & 1.19 & 2.46 & 0.07 & -1.55 & 0.13 \\
\hline Content Manager Specialist & 2.48 & 1.24 & 2.37 & 0.06 & -1.62 & 0.13 \\
\hline Project Manager & 3.26 & 0.95 & 3.56 & -1.07 & 0.04 & 0.10 \\
\hline Storage Services Specialist & 2.27 & 1.23 & 2.03 & 0.30 & -1.55 & 0.14 \\
\hline Systems Programmer & 2.86 & 1.11 & 3.00 & -0.34 & -1.34 & 0.12 \\
\hline Server Services Specialist & 2.85 & 1.18 & 3.13 & -0.49 & -1.31 & 0.13 \\
\hline Security Services Specialist & 2.82 & 1.22 & 3.13 & -0.41 & -1.46 & 0.13 \\
\hline Network Services Specialist & 2.85 & 1.18 & 3.12 & -0.44 & -1.37 & 0.13 \\
\hline Infrastructure Specialist & 2.73 & 1.25 & 2.92 & -0.26 & -1.60 & 0.14 \\
\hline Database Administrator & 3.02 & 1.09 & 3.33 & -0.67 & -0.95 & 0.12 \\
\hline Test Specialist & 2.86 & 1.11 & 3.07 & -0.55 & -1.07 & 0.12 \\
\hline Data Specialist & 2.61 & 1.16 & 2.74 & -0.17 & -1.45 & 0.13 \\
\hline Integration Specialist & 2.57 & 1.11 & 2.72 & -0.18 & -1.34 & 0.12 \\
\hline Application Developer & 3.30 & 1.02 & 3.69 & -1.17 & -0.05 & 0.11 \\
\hline Business Analyst & 2.90 & 1.03 & 3.04 & -0.47 & -1.01 & 0.11 \\
\hline
\end{tabular}

\section{Trained Workforce Availability for Job Roles}

To estimate the level of skills existing for each of the basic ICT jobs, companies were requested to rank the trained workforce available for each role of ICT by using scale ranks from 1 (unavailable) to 4 (too many). Results showed that the highest ranking in the availability of a very large number of trained workforce was for Systems Programmer. Three roles were ranked second: Application Developer, Database Administrator, and Project Manager. The third place was related to Infrastructure Specialist.

The lowest level was for Test Specialist, Security Services Specialist, Storage Service Specialist, and Application Specialist. Packaged Application Specialist has the lowest job role in terms of the availability of the trained workforce, because about one-third of the companies believe that there is no trained workforce available for this role. The second place is for Storage Services Specialist followed by Portal \& Collaboration Specialist and Content Manager Specialist.

With regard to the jobs that companies indicated had an adequately trained workforce, the highest rank was for Application Developer. The second rank was Database Administrator. The third rank was for System Programmers and Network and Services, and the fifth place for Project Managers. The least job role with sufficiently available trained manpower was Packed Application Specialist. 
Table 3. Availability of trained workforce of job roles (\%)

\begin{tabular}{|c|c|c|c|c|c|}
\hline Job Role & $\begin{array}{c}\text { No available } \\
\text { trained workforce } \\
\text { (1) }\end{array}$ & $\begin{array}{c}\text { Few available } \\
\text { trained workforce } \\
(2)\end{array}$ & $\begin{array}{c}\text { Enough available } \\
\text { trained workforce } \\
\text { (3) }\end{array}$ & $\begin{array}{c}\text { Too much available } \\
\text { trained workforce } \\
\text { (4) }\end{array}$ & $\begin{array}{c}\text { No } \\
\text { Answer }\end{array}$ \\
\hline Portals \& Collaboration & 23 & 25 & 20 & 5 & 27 \\
\hline Packaged Application Specialist & 32 & 28 & 9 & 4 & 27 \\
\hline Content Manager Specialist & 23 & 28 & 19 & 8 & 22 \\
\hline Project Manager & 11 & 36 & 29 & 13 & 11 \\
\hline Storage Services Specialist & 28 & 23 & 16 & 4 & 29 \\
\hline Systems Programmer & 9 & 28 & 32 & 15 & 16 \\
\hline Server Services Specialist & 16 & 28 & 28 & 7 & 21 \\
\hline Security Services Specialist & 19 & 32 & 24 & 4 & 21 \\
\hline Network Services Specialist & 8 & 35 & 32 & 8 & 17 \\
\hline Infrastructure Specialist & 19 & 29 & 23 & 9 & 20 \\
\hline Database Administrator & 11 & 29 & 33 & 14 & 13 \\
\hline Test Specialist & 15 & 35 & 25 & 4 & 21 \\
\hline Data Specialist & 19 & 33 & 19 & 5 & 24 \\
\hline Integration Specialist & 16 & 43 & 13 & 8 & 20 \\
\hline Application Developer & 9 & 25 & 40 & 14 & 12 \\
\hline Business Analyst & 17 & 44 & 17 & 6 & 16 \\
\hline
\end{tabular}

Table 4. Statistic summaries of trained workforce of job roles

\begin{tabular}{lcccccc}
\hline Job Role & Mean & S. Deviation & Median & Skewness & Kurtosis & S. Error \\
\hline Portals \& Collaboration & 2.10 & 0.93 & 2.04 & 0.32 & -0.95 & 0.11 \\
\hline Packaged Application Specialist & 1.79 & 0.87 & 1.66 & 0.91 & 0.09 & 0.10 \\
\hline Content Manager Specialist & 2.15 & 0.97 & 2.07 & 0.37 & -0.91 & 0.11 \\
\hline Project Manager & 2.49 & 0.89 & 2.43 & 0.11 & -0.78 & 0.09 \\
\hline Storage Services Specialist & 1.94 & 0.92 & 1.83 & 0.54 & -0.80 & 0.11 \\
\hline Systems Programmer & 2.63 & 0.90 & 2.66 & -0.10 & -0.82 & 0.10 \\
\hline Server Services Specialist & 2.33 & 0.90 & 2.34 & 0.04 & -0.89 & 0.10 \\
\hline Security Services Specialist & 2.16 & 0.85 & 2.14 & 0.17 & -0.81 & 0.10 \\
\hline Network Services Specialist & 2.48 & 0.80 & 2.46 & 0.06 & -0.52 & 0.09 \\
\hline Infrastructure Specialist & 2.28 & 0.95 & 2.22 & 0.22 & -0.94 & 0.11 \\
\hline Database Administrator & 2.57 & 0.91 & 2.61 & -0.08 & -0.83 & 0.10 \\
\hline Test Specialist & 2.23 & 0.82 & 2.20 & 0.13 & -0.64 & 0.09 \\
\hline Data Specialist & 2.13 & 0.87 & 2.08 & 0.35 & -0.63 & 0.10 \\
\hline Integration Specialist & 2.16 & 0.86 & 2.06 & 0.62 & -0.15 & 0.10 \\
\hline Application Developer & 2.67 & 0.87 & 2.75 & -0.26 & -0.60 & 0.09 \\
\hline Business Analyst & 2.14 & 0.82 & 2.07 & 0.50 & -0.16 & 0.09 \\
\hline
\end{tabular}

Furthermore, we can notice that the highest ratio of job roles with few available manpower was for Business Analyst, followed by Integration Specialists, and then Project Managers. The lowest category was for Storage Services Specialists. Table 3 shows the availability percent of the trained workforce for core job roles. Table 4 presents statistic summaries of the trained workforce for core job roles.

\section{New Graduates and their Proficiency Level for Core Job Roles}

For each ICT job role, companies were requested to rank the attained skills of new graduates using a fourcategory assessment scale (1: No skills, 2: Acquired skills, 3: Applied skills, 4: Expert skills). For the expert skill category, the companies' assessment ratios for main job roles were not high; moreover the values were concentrated with small inconsistencies, which meant small differences have been noticed among them. The highest rank in this category was for the role of Project Manager since $8 \%$ of the respondents pointed out that new graduates have expert skills for this role followed by Business Analyst. Server Service Specialist and Data Specialists were ranked third. The fourth level has acquired five job roles; Infrastructure Specialist, Network Service Specialist, Database Administrator, Content Manager Specialist, and Test Specialist. The lowest rate for Packaged Application Specialist.

As for the companies' awareness of applied skills, the highest percentage ( $20 \%$ of the participants) indicated that the skills of the new graduates of System Programmer are applied skills, while this role ranked third in terms of acquired skills. The next rank was for Database Administrator, while it was ranked as the fifth place in terms of gained skills, and the third for Test Specialist. Server Service Specialist, Application Developer, and Data Specialist were 
Table 5. Proficiency level of fresh graduate (\%)

\begin{tabular}{|c|c|c|c|c|c|}
\hline Job Role & $\begin{array}{c}\text { No skills } \\
(1)\end{array}$ & $\begin{array}{c}\text { Acquired skills } \\
(2)\end{array}$ & $\begin{array}{c}\text { Applied skills } \\
\text { (3) }\end{array}$ & $\begin{array}{c}\text { Expert skills } \\
(4)\end{array}$ & No Answer \\
\hline Portals \& Collaboration & 33 & 32 & 4 & 3 & 28 \\
\hline Packaged Application Specialist & 37 & 24 & 9 & 2 & 28 \\
\hline Content Manager Specialist & 33 & 29 & 9 & 5 & 24 \\
\hline Project Manager & 33 & 36 & 11 & 8 & 12 \\
\hline Storage Services Specialist & 31 & 32 & 4 & 3 & 30 \\
\hline Systems Programmer & 24 & 37 & 20 & 3 & 16 \\
\hline Server Services Specialist & 31 & 29 & 12 & 5 & 23 \\
\hline Security Services Specialist & 29 & 35 & 11 & 3 & 22 \\
\hline Network Services Specialist & 24 & 43 & 11 & 4 & 18 \\
\hline Infrastructure Specialist & 31 & 35 & 9 & 5 & 21 \\
\hline Database Administrator & 25 & 36 & 19 & 4 & 16 \\
\hline Test Specialist & 32 & 29 & 13 & 4 & 21 \\
\hline Data Specialist & 31 & 27 & 12 & 5 & 25 \\
\hline Integration Specialist & 32 & 33 & 9 & 3 & 23 \\
\hline Application Developer & 23 & 51 & 12 & 3 & 11 \\
\hline Business Analyst & 41 & 29 & 5 & 8 & 17 \\
\hline
\end{tabular}

Table 6. Statistic summaries of proficiency level of fresh graduate

\begin{tabular}{lcccccc}
\hline Job Role & Mean & S. Deviation & Median & Skewness & Kurtosis & S. Error \\
\hline Portals \& Collaboration & 1.68 & 0.77 & 1.59 & 1.15 & 1.29 & 0.09 \\
\hline Packaged Application Specialist & 1.67 & 0.80 & 1.47 & 0.98 & 0.15 & 0.09 \\
\hline Content Manager Specialist & 1.82 & 0.89 & 1.67 & 0.92 & 0.06 & 0.10 \\
\hline Project Manager & 1.93 & 0.93 & 1.81 & 0.81 & -0.21 & 0.10 \\
\hline Storage Services Specialist & 1.70 & 0.77 & 1.63 & 1.12 & 1.23 & 0.09 \\
\hline Systems Programmer & 2.02 & 0.82 & 1.99 & 0.34 & -0.63 & 0.09 \\
\hline Server Services Specialist & 1.88 & 0.90 & 1.76 & 0.76 & -0.30 & 0.10 \\
\hline Security Services Specialist & 1.85 & 0.81 & 1.79 & 0.72 & -0.01 & 0.09 \\
\hline Network Services Specialist & 1.94 & 0.79 & 1.90 & 0.70 & 0.26 & 0.09 \\
\hline Infrastructure Specialist & 1.82 & 0.83 & 1.74 & 0.87 & 0.26 & 0.09 \\
\hline Database Administrator & 2.02 & 0.85 & 1.97 & 0.42 & -0.59 & 0.09 \\
\hline Test Specialist & 1.89 & 0.91 & 1.76 & 0.73 & -0.37 & 0.10 \\
\hline Data Specialist & 1.88 & 0.91 & 1.74 & 0.76 & -0.36 & 0.11 \\
\hline Integration Specialist & 1.78 & 0.80 & 1.70 & 0.86 & 0.24 & 0.09 \\
\hline Application Developer & 1.94 & 0.73 & 1.92 & 0.61 & 0.46 & 0.08 \\
\hline Business Analyst & 1.76 & 0.94 & 1.52 & 1.17 & 0.44 & 0.10 \\
\hline
\end{tabular}

ranked fourth. The lowest rank was for Portal and Collaboration Specialist and Storage Service Specialist, while $32 \%$ of the respondents believed that the skills available to new graduates of these two roles were acquired skills.

The results also showed that more than $40 \%$ of the respondents (the highest percentage) indicated that new graduates do not have skills of Business Analyst, while the second place is related to Packaged Application Specialist. The third level relates to Portal and Collaboration Specialist, Content Manager Specialist, and Project Manager. The fourth level was for both Integration Specialists and Test Specialists. Server Service Specialist, Infrastructure Specialist, Storage Service Specialist, and Data Specialist were ranked fifth. Application Developer was ranked, which is the highest level of acquired skills. Tables 5 and $\mathbf{6}$ show the overall statistical analyses.

\section{Number of Fresh Graduates to Be Hired}

Each year, there is a need to hire new employees to cover the demand and expansion of the Jordanian ICT sector. The goal of this subsection is to measure the demand volume for each job and therefore asks companies to provide their forecasts for the number of new graduates they plan to employ for each specific job role.

Application Developer gained the largest demand size, where all companies plan to hire as of total 256 new graduates for this role. The results revealed that all of the other jobs are required but not as much as required as the Application Developer. The next job required is Project Manager with 82 appointments of new graduates for this role, followed by Content Manager Specialist with 78 new graduates. While 73 graduates are needed for the role of Business Analyst, 64 graduates for System Programmer, the least is for Storage Service Specialist with the demand of 17 graduates. These results are consistent with the results presented in job roles important subsection. The results 
Table 7. Fresh graduates needed to be hired for each job role

\begin{tabular}{lll}
\hline Job Role & Total & Percent \% \\
\hline Application Developer & 256 & 25.2 \\
\hline Project Manager & 82 & 8.1 \\
\hline Content Manager Specialist & 78 & 7.7 \\
\hline Business Analyst & 73 & 7.2 \\
\hline Systems Programmer & 64 & 6.3 \\
\hline Test Specialist & 59 & 5.8 \\
\hline Database Administrator & 58 & 5.7 \\
\hline Network Services Specialist & 55 & 5.4 \\
\hline Infrastructure Specialist & 52 & 5.1 \\
\hline Integration Specialist & 46 & 4.5 \\
\hline Server Services Specialist & 42 & 4.1 \\
\hline Data Specialist & 37 & 3.6 \\
\hline Security Services Specialist & 34 & 3.3 \\
\hline Packaged Application Specialist & 33 & 3.2 \\
\hline Portals \& Collaboration & 30 & 3 \\
\hline Storage Services Specialist & 17 & 1.7 \\
\hline
\end{tabular}

showed that the majority of companies (57\%) believe that the role of Application Developer is of high importance in the present and future, and the results of this subsection reveal that this role is the most sought after. These results present a good picture of actual market needs and draw attention to the importance of bridging the gap between market forces; supply and demand. Table 7 shows the demand volume of new graduates to be recruited for each job.

\section{Technologies Needed}

Companies are requested to measure the current and future (over 5 years) importance of each the identified technologies through analyzing the companies' perception of each technology. For technologies that are of great importance today and in the future, Database Systems has the highest ratings. Followed by Enterprise Development, Web Development, and Enterprise Resource Planning. The latter rank was for the Supply Chain, while it has the highest in term of low current and low future importance.

With regard to the second set of evaluation (technologies of low current importance but expected to have high future importance). Customer Relationship Management gained the highest percentage of respondents, with $23 \%$ of companies indicated that this technology is of low importance at present but is expected to be of high importance in the future. The second is Uniform Modeling Language. The third is Enterprise Resource Planning, Supply Chain, Business Intelligence, and Web 2.0. The fourth place is Enterprise Content Management, while the latter was a set of two technologies: Infrastructure Monitoring and Web Development. The overall results are summarized in Tables 8 and 9. 
Table 8. Current and future importance of technology skills (\%)

\begin{tabular}{lccccc}
\hline Technology Skill & $\begin{array}{c}\text { LOW current } \\
\text { Importance and } \\
\text { LOW future }\end{array}$ & $\begin{array}{c}\text { LOW current } \\
\text { Importance (1) } \\
\text { Importure HIGH } \\
\text { Importance (2) }\end{array}$ & $\begin{array}{c}\text { Moderate } \\
\text { Current and } \\
\text { future } \\
\text { Importance (3) }\end{array}$ & $\begin{array}{c}\text { Current HIGH } \\
\text { Importance and } \\
\text { future HIGH }\end{array}$ Importance (4) \\
Imswer
\end{tabular}

Table 9. Statistic summaries of current and future importance of technology skills

\begin{tabular}{lcccccc}
\hline Job Role & Mean & S. Deviation & Median & Skewness & Kurtosis & S. Error \\
\hline Web 2.0 (AJAX, Wikis, Social Networks) & 3.25 & 0.86 & 3.48 & -0.81 & -0.42 & 0.09 \\
\hline CRM (Customer Relationship Management) & 3.04 & 1.06 & 3.30 & -0.73 & -0.80 & 0.12 \\
\hline Cloud Computing \& Virtualization & 2.88 & 1.17 & 3.17 & -0.56 & -1.21 & 0.13 \\
\hline Business Intelligence (Business Analytics, DWH) & 2.75 & 1.15 & 2.84 & -0.25 & -1.42 & 0.13 \\
\hline AIM - BPM (Business Process Management), BPEL & 2.67 & 1.21 & 2.87 & -0.26 & -1.52 & 0.14 \\
\hline Enterprise Content Management & 2.39 & 1.23 & 2.18 & 0.20 & -1.59 & 0.14 \\
\hline Infrastructure Monitoring (Tivoli, HP) & 2.56 & 1.06 & 2.55 & -0.04 & -1.26 & 0.12 \\
\hline SOA (Service Oriented Architecture) & 2.20 & 1.19 & 1.97 & 0.38 & -1.41 & 0.14 \\
\hline UML (Unified Modelling Language), RUP & 2.60 & 1.02 & 2.68 & -0.16 & -1.13 & 0.12 \\
\hline Supply Chain Management & 2.47 & 1.11 & 2.59 & -0.05 & -1.38 & 0.13 \\
\hline Web 2.0 (AJAX, Wikis, Social Networks) & 2.39 & 1.13 & 2.35 & 0.12 & -1.40 & 0.14 \\
\hline CRM (Customer Relationship Management) & 2.24 & 1.15 & 2.28 & 0.18 & -1.50 & 0.14 \\
\hline Cloud Computing \& Virtualization & 2.07 & 1.11 & 1.83 & 0.44 & -1.30 & 0.13 \\
\hline Business Intelligence (Business Analytics, DWH) & 2.06 & 1.03 & 1.90 & 0.50 & -1.03 & 0.12 \\
\hline AlM - BPM (Business Process Management), BPEL & 1.93 & 0.98 & 1.74 & 0.59 & -0.89 & 0.12 \\
\hline
\end{tabular}

\section{Availability of Technology Skills of Fresh Graduates}

To assess the availability of technology skills of new graduates, companies were requested to rank the availability of technology skills of new graduates using a four-category assessment scale (1: No available, 2: Few available, 3: Enough available, 4: Too much). The results of the analysis showed that most companies think that majority of new graduates do not have trained workforce for most technologies. In addition, the results showed small percentage of companies that have pointed out the availability of too much ones.

The technology skill that was ranked the highest in terms of "No available" is Cloud Computing and Virtualization. The second is Business Process Management. The third is Business Intelligence. The fourth is Supply Chain Management. The fifth category is Service-Oriented Architecture. The last technology in terms of "No available" trained workforce is Database Systems.

The technology that was ranked the highest in terms of "few available" trained workforce is Database Systems. Pointing out that it has ranked first in terms of high current and future importance. The second rank is Web Development. The third is Enterprise Development. Ranked fourth is Web2.0 followed by Customer Relationship 
Table 10. Availability technology skills of fresh graduate

\begin{tabular}{|c|c|c|c|c|c|}
\hline Technology Skill & $\begin{array}{c}\text { No available } \\
\text { trained } \\
\text { workforce (1) }\end{array}$ & $\begin{array}{c}\text { Few available } \\
\text { trained } \\
\text { workforce (2) }\end{array}$ & $\begin{array}{c}\text { Enough available } \\
\text { trained } \\
\text { workforce (3) } \\
\end{array}$ & $\begin{array}{c}\text { Too much } \\
\text { available trained } \\
\text { workforce (4) }\end{array}$ & $\begin{array}{c}\text { No } \\
\text { Answer }\end{array}$ \\
\hline Data Base Systems (Oracle, MS SQL, DB2) & 13 & 40 & 27 & 8 & 12 \\
\hline $\begin{array}{l}\text { Enterprise Development (J2EE, .Net, VB, } \\
\mathrm{C}++ \text { ) }\end{array}$ & 15 & 37 & 19 & 9 & 20 \\
\hline $\begin{array}{l}\text { Web Development (Java, Apache, PHP, } \\
\text { ASP.Net) }\end{array}$ & 19 & 39 & 20 & 7 & 15 \\
\hline ERP (Enterprise Resource Planning) & 35 & 23 & 16 & 3 & 23 \\
\hline $\begin{array}{l}\text { Network Security and Infrastructure (Cisco, } \\
\text { IBM) }\end{array}$ & 23 & 27 & 20 & 7 & 23 \\
\hline Web 2.0 (AJAX, Wikis, Social Networks) & 29 & 29 & 12 & 3 & 27 \\
\hline CRM (Customer Relationship Management) & 33 & 27 & 12 & 1 & 27 \\
\hline Cloud Computing \& Virtualization & 44 & 17 & 8 & 1 & 29 \\
\hline $\begin{array}{l}\text { Business Intelligence (Business Analytics, } \\
\text { DWH) }\end{array}$ & 40 & 19 & 12 & 1 & 28 \\
\hline $\begin{array}{l}\text { AIM - BPM (Business Process } \\
\text { Management), BPEL }\end{array}$ & 41 & 15 & 16 & 0 & 28 \\
\hline Enterprise Content Management & 31 & 27 & 8 & 3 & 31 \\
\hline Infrastructure Monitoring (Tivoli, HP) & 35 & 17 & 15 & 0 & 33 \\
\hline SOA (Service Oriented Architecture) & 37 & 17 & 9 & 2 & 35 \\
\hline UML (Unified Modelling Language), RUP & 32 & 25 & 13 & 1 & 29 \\
\hline Supply Chain Management & 39 & 17 & 8 & 1 & 35 \\
\hline
\end{tabular}

Table 11. Statistic summaries of availability technology skills of fresh graduate

\begin{tabular}{lcccccc}
\hline Job Role & Mean & S. Deviation & Median & Skewness & Kurtosis & S. Error \\
\hline Web 2.0 (AJAX, Wikis, Social Networks) & 2.34 & 0.84 & 2.28 & 0.22 & -0.56 & 0.09 \\
\hline CRM (Customer Relationship Management) & 2.28 & 0.90 & 2.18 & 0.37 & -0.62 & 0.10 \\
\hline Cloud Computing \& Virtualization & 2.18 & 0.88 & 2.10 & 0.39 & -0.53 & 0.09 \\
\hline $\begin{array}{l}\text { Business Intelligence (Business Analytics, } \\
\text { DWH) }\end{array}$ & 1.83 & 0.89 & 1.65 & 0.66 & -0.71 & 0.10 \\
\hline $\begin{array}{l}\text { AIM - BPM (Business Process Management), } \\
\text { BPEL }\end{array}$ & 2.14 & 0.96 & 2.07 & 0.34 & -0.93 & 0.11 \\
\hline Enterprise Content Management & 1.85 & 0.84 & 1.76 & 0.69 & -0.30 & 0.10 \\
\hline Infrastructure Monitoring (Tivoli, HP) & 1.74 & 0.78 & 1.63 & 0.65 & -0.57 & 0.09 \\
\hline SOA (Service Oriented Architecture) & 1.55 & 0.81 & 1.31 & 1.29 & 0.73 & 0.10 \\
\hline UML (Unified Modelling Language), RUP & 1.64 & 0.81 & 1.40 & 0.88 & -0.45 & 0.10 \\
\hline Supply Chain Management & 1.65 & 0.82 & 1.38 & 0.70 & -1.19 & 0.10 \\
\hline Web 2.0 (AJAX, Wikis, Social Networks) & 1.75 & 0.83 & 1.63 & 0.93 & 0.24 & 0.10 \\
\hline CRM (Customer Relationship Management) & 1.70 & 0.82 & 1.46 & 0.58 & -1.28 & 0.10 \\
\hline Cloud Computing \& Virtualization & 1.63 & 0.84 & 1.38 & 1.07 & 0.12 & 0.10 \\
\hline $\begin{array}{l}\text { Business Intelligence (Business Analytics, } \\
\text { DWH) }\end{array}$ & 1.76 & 0.80 & 1.64 & 0.61 & -0.72 & 0.10 \\
\hline $\begin{array}{l}\text { AIM - BPM (Business Process Management), } \\
\text { BPEL }\end{array}$ & 1.55 & 0.77 & 1.33 & 1.13 & 0.27 & 0.10 \\
\hline
\end{tabular}

Management. The latter rank is Business Process Management. The highest ratio in terms of availability of sufficient trained graduates was for Database Systems. Tables 10 and $\mathbf{1 1}$ summarize the overall results.

\section{Availability of Technology Skills of Existing Staff}

To assess the availability of technological skills of existing employees, companies were asked to rank the availability of technological skills of their existing employees using a four-tier rating scale (from no available to too many). Unfortunately, most companies indicated that there were no trained staff available for most of the technologies skills. Database Systems gained the highest ranking in terms of too many available trained staff. The second is Enterprise Development. The third is Web Development. The fourth is for Network Security and Enterprise Resource Planning. The last is Service-Oriented Architecture. 
Table 12. Availability technology skills of existing employees

\begin{tabular}{|c|c|c|c|c|c|}
\hline Technology Skill & $\begin{array}{c}\text { No available } \\
\text { trained } \\
\text { workforce (1) }\end{array}$ & $\begin{array}{c}\text { Few available } \\
\text { trained } \\
\text { workforce (2) }\end{array}$ & $\begin{array}{c}\text { Enough available } \\
\text { trained workforce } \\
\text { (3) }\end{array}$ & $\begin{array}{c}\text { Too much } \\
\text { available trained } \\
\text { workforce (4) } \\
\end{array}$ & $\begin{array}{c}\text { No } \\
\text { Answer }\end{array}$ \\
\hline Data Base Systems (Oracle, MS SQL, DB2) & 5 & 19 & 43 & 23 & 10 \\
\hline $\begin{array}{l}\text { Enterprise Development (J2EE, .Net, VB, } \\
\mathrm{C}++ \text { ) }\end{array}$ & 16 & 20 & 27 & 19 & 18 \\
\hline $\begin{array}{l}\text { Web Development (Java, Apache, PHP, } \\
\text { ASP.Net) }\end{array}$ & 23 & 21 & 25 & 18 & 13 \\
\hline ERP (Enterprise Resource Planning) & 23 & 16 & 24 & 15 & 22 \\
\hline $\begin{array}{l}\text { Network Security and Infrastructure (Cisco, } \\
\text { IBM) }\end{array}$ & 23 & 17 & 23 & 15 & 22 \\
\hline Web 2.0 (AJAX, Wikis, Social Networks) & 31 & 16 & 17 & 12 & 24 \\
\hline CRM (Customer Relationship Management) & 23 & 24 & 21 & 7 & 25 \\
\hline Cloud Computing \& Virtualization & 35 & 16 & 15 & 5 & 29 \\
\hline $\begin{array}{l}\text { Business Intelligence (Business Analytics, } \\
\text { DWH) }\end{array}$ & 19 & 31 & 15 & 9 & 26 \\
\hline $\begin{array}{l}\text { AIM - BPM (Business Process } \\
\text { Management), BPEL }\end{array}$ & 25 & 23 & 17 & 7 & 28 \\
\hline Enterprise Content Management & 31 & 16 & 15 & 8 & 30 \\
\hline Infrastructure Monitoring (Tivoli, HP) & 31 & 13 & 16 & 7 & 33 \\
\hline SOA (Service Oriented Architecture) & 32 & 16 & 17 & 3 & 32 \\
\hline UML (Unified Modelling Language), RUP & 32 & 21 & 12 & 7 & 28 \\
\hline Supply Chain Management & 35 & 19 & 12 & 4 & 30 \\
\hline
\end{tabular}

Table 13. Statistic summaries of availability technology skills of existing employees

\begin{tabular}{lcccccc}
\hline Job Role & Mean & S. Deviation & Median & Skewness & Kurtosis & S. Error \\
\hline Web 2.0 (AJAX, Wikis, Social Networks) & 2.93 & 0.83 & 2.99 & -0.46 & -0.35 & 0.09 \\
\hline CRM (Customer Relationship Management) & 2.60 & 1.05 & 2.69 & -0.16 & -1.20 & 0.12 \\
\hline Cloud Computing \& Virtualization & 2.44 & 1.10 & 2.48 & 0.03 & -1.34 & 0.12 \\
\hline Business Intelligence (Business Analytics, DWH) & 2.40 & 1.11 & 2.50 & 0.03 & -1.39 & 0.13 \\
\hline AIM - BPM (Business Process Management), BPEL & 2.38 & 1.11 & 2.44 & 0.06 & -1.38 & 0.13 \\
\hline Enterprise Content Management & 2.13 & 1.12 & 1.94 & 0.41 & -1.29 & 0.13 \\
\hline Infrastructure Monitoring (Tivoli, HP) & 2.16 & 0.97 & 2.10 & 0.29 & -1.03 & 0.11 \\
\hline SOA (Service Oriented Architecture) & 1.86 & 0.99 & 1.53 & 0.71 & -0.81 & 0.12 \\
\hline UML (Unified Modelling Language), RUP & 2.19 & 0.96 & 2.08 & 0.45 & -0.76 & 0.11 \\
\hline Supply Chain Management & 2.08 & 0.99 & 1.98 & 0.44 & -0.96 & 0.12 \\
\hline Web 2.0 (AJAX, Wikis, Social Networks) & 2.00 & 1.06 & 1.75 & 0.57 & -1.05 & 0.13 \\
\hline CRM (Customer Relationship Management) & 1.99 & 1.07 & 1.69 & 0.55 & -1.13 & 0.13 \\
\hline Cloud Computing \& Virtualization & 1.87 & 0.94 & 1.63 & 0.57 & -1.00 & 0.11 \\
\hline Business Intelligence (Business Analytics, DWH) & 1.92 & 1.00 & 1.69 & 0.74 & -0.66 & 0.12 \\
\hline AIM - BPM (Business Process Management), BPEL & 1.79 & 0.93 & 1.50 & 0.85 & -0.42 & 0.11 \\
\hline
\end{tabular}

Regarding the availability of trained staff on specific technologies, Database Systems is the technology that has the highest proportion of adequately trained staff. Enterprise Development comes second. The third is Web Development followed by Enterprise Resource Planning and Network Security. The latter is Supply Chain Management. The technology that has a few trained staff is Business Intelligence. Tables 12 and 13 summarize all obtained results.

\section{RECOMMENDATIONS}

Based on the findings of this study, the following are recommendations for different stakeholders:

\section{Government and Policy Makers}

- Strengthening the role of government as a vital player in empowering partnerships among industry, private sector, and academic and research centers. The government should enforce the integration of innovation approaches within educational institutions. 
- Promote, improve, and evaluate existing tools and studies used to get the right balance between labor demand and supply. A periodic assessment is needed to forecast the future market demand and then to align the strategic plans of the solicitous parties appropriately.

- Implement a tracking system with the help of the Civil Service Bureau to identify career paths in the ICT sector and plan future academic programs appropriately.

- Develop appropriate policies and programs in order to enhance the female participation in the ICT labor force.

- Support ICT companies financially to encourage them develop training plans for new graduates.

\section{The Private Sector}

- Make professional visits to academic institutions, get together with instructors and students and provide time to present technical and awareness sessions.

- Encourage professional staff to acquire and work within the concept of teamwork.

- Pay further attention to the most important professional jobs now and in the future, continual review for jobs that are not important either now or in the future. Also, further attention is required for the jobs that are expected to be of importance in the future to ensure that they are aligned with the strategic plans of the academic community.

- Secure annual financial budget for collaboration with academic and research centers and provide education institutions with the confidence to invest. This budget can be used to sponsor graduation projects, support curriculum development, fund research proposals.

- Develop and share strategic plans with other stakeholders to ensure homogeneity with their policies, and ensure that new graduates will meet labor market needs.

- Come up with appropriate practices to match labor market needs and job requirements with the existing level of skills.

\section{Universities \& Academic Institutes}

- Plan to develop and build a dynamic high level quality and relevant, industry oriented ICT education through cooperation with all partnerships.

- Develop and maintain dynamic educational programs driven by dynamic curriculum and instructional practices to provide the graduates with pertinent knowledge and skills.

- Support research and development at academic and research centers and align it to labor market needs of technology skills.

- Develop and apply proper approaches to improve the quality of education and training of private university graduates to compete with graduates of public universities in the labor market.

- Provide students with business and soft skills and offer related capacity building and training development programs.

- Strongly considering teaching Business English course as an elective and gradually substitute it with the basic English course.

- Focus on helping students acquire teamwork skills (negotiation, collaboration, and cooperation) by encouraging them to work on course-based projects.

\section{All Stakeholders}

- Develop, improve, and expand internship opportunities with industry to align learning outcomes with the current and practical technology skills needed by labor market.

- Encourage the knowledge transfer by promoting the transfer of people and their skills among academic institutions, government, and industry.

- Establish solid bridges and cooperation between partnerships to study the labor market needs of technologies, to facilitate the use of newly innovated technologies, and to provide professionals and experts for the most important ones. 
- Honor and place emphasis on academic success stories. Great strides have been made towards curriculum development by many academic institutions and their accomplishments can serve as a role model for others.

- Disseminate and give emphasis to success achievements and cooperation between academia, the industry, and the government.

- Establish communication links between all partnerships and be open to new ideas from all sides.

\section{CONCLUSION}

The service sector is the topmost growing share of the developed economies. The dependency of this sector on information technology (IT) deserves curricula revision of most IT related academic programs. As the discipline of computing endures to expand and diversify, and new computing-related academic programs arise, existing curriculum of academic programs must be updated regularly and new computing disciplines will be originated. This has made the need to develop an interdisciplinary curriculum to prepare university graduates entering the workforce with depth and breadth of skills needed for service sector industries a necessary issue.

The development of curricular guidelines for SSME is particularly challenging. The growing diversity of topics in SSME and the increasing integration of computing with other disciplines (e.g., computer science (Thompson, Bellanca, Owens, \& Lorenzo, 2012), business (Conger, 2009), and engineering (Rozenes \& Kukliansky, 2014)) create additional challenges. As a result, there is a need to establish international curricular guidelines for a new Bachelor's degree in SSME that will match the latest developments in the discipline and have lasting impact.

In this paper, we have presented and briefly discussed a feasibility study as a basis for establishing an undergraduate program that offers a Bachelor's degree in SSME. First, we identified the body of knowledge areas and skills needed by SSME graduates to compete in the knowledge-based service economy. Secondly, we presented justifications for establishing the new undergraduate SSME program. Finally, we provided the resources considered necessary for establishing SSME department. The establishment of this emerging degree program allows JUST, firstly, to cross the boundaries of traditional IT curricula and respond to an industry need that traditional IT disciplines do not serve, and secondly, to take a unique and pioneering step in this field and thus being the first university in Jordan and in the Middle East in offering this program.

\section{REFERENCES}

Al-Badarneh, A., Spohrer, J., \& Al-Duwairi, B. (2013). A model curriculum for undergraduate program in IT SSME. International Journal of Service Science, Management, Engineering, and Technology, 4, 1-18. https:/ / doi.org/10.4018/ijssmet.2013100101

Beblavý, M., Fabo, B., \& Lenearts, K. (2016, December). Demand for Digital Skills in the US Labour Market: The IT Skills Pyramid. Centre for European Policy Studies (CEPS) Catalogue, Special Report No. 154.

Bureau of Labor Statistics. (2016, December). The Employment Situation (USDL-17-0004). Washington, DC: US Department of Labor. Retrieved on January 6, 2017 from https:/ / www.bls.gov/news.release/archives/empsit_01062017.pdf

Chesbrough, H. (2004, September 24). A failing grade for innovation academy. Financial Times. Retrieved on August 1, 2016 from http:/ / www.ft.com

Conger, S. (2009). Information technology service management and opportunities for information systems curricula. International Journal of Information Systems in the Service Sector, 1, 58-68. https:/ / doi.org/10.4018/jisss.2009040104

Daniels, P. W. (2012). Service industries at a crossroads: some fragile assumptions and future challenges. The Service Industries Journal, 32, 619-639. https:/ / doi.org/10.1080/02642069.2011.596536

Fitzsimmons, J. A., Fitzsimmons, M. J., \& Bordoloi, S. (2014). Service Management: Operations, Strategy, Information Technology (8th ed.). Boston, MA: Mc Graw Hill.

Hefley, B., \& Murphy, W. (Eds.) (2008). Service Science, Management and Engineering: Education for the 21st Century Series. New York, NY: Springer. https:/ / doi.org/10.1007/978-0-387-76578-5

Ministry of Information and Communications Technology. (2010). Workforce in Jordanian ICT Industry: Evaluation and Needs Assessment 2010. Jordan: MoICT. Retrieved on January 7, 2015 from http:/ / moict.gov.jo/uploads/Policies-and-Strategies-Directorate/Surveys/Workforce-in-Jordanian-ICTIndustries/Evaluation-and-Needs-Assessment-of-Workforce-in-Jordanian-ICT-Industries-2010.pdf

Ministry of Information and Communications Technology. (2013). Jordan National Information and Communications Technology Strategy (2013-2017). Jordan: MoICT. Retrieved on March 23, 2015 from 
http:/ / moict.gov.jo/uploads/Policies-and-Strategies-Directorate/Strategies/Jordan-NationalInformation-and-Communications-Technology-Strategy-2013-2017.pdf

Ministry of Information and Communications Technology. (2016). ICT and ITES Industry Statistics and Yearbook. Jordan: MoICT. Retrieved on April 2, 2016 from http://moict.gov.jo/uploads/Policies-and-StrategiesDirectorate/Surveys/Industries/ICTandITES-Industry-StatisticsandYearbook-2016.pdf

Ministry of Information and Communications Technology. (2016). Jordan National Information and Communications Technology Strategy (2013-2017). Jordan: MoICT. Retrieved on April 23, 2017 from http:/ / moict.gov.jo/uploads/Policies-and-Strategies-Directorate/Strategies/Jordan-NationalInformation-and-Communications-Technology-Strategy-2013-2017.pdf

Rozenes, S., \& Kukliansky, I. (2014). An innovative design approach to new service development learning processes. International Journal of Information Systems in the Service Sector, 6, 27-39. https:/ / doi.org/10.4018/ijisss.2014100102

Solnet, D. (2012). Service management in hospitality education: Review and reflection. Journal of Hospitality Marketing \& Management, 21, 184-214. https:/ / doi.org/10.1080/19368623.2011.584267

Soubbotina, T. P., \& Sheram, K. A. (2000). Beyond Economic Growth: Meeting the Challenges of Global Development. WBI Learning Resources. Washington, DC: World Bank. (c) World Bank. https://openknowledge.worldbank.org/handle/10986/15789 License: CC BY 3.0 IGO.

Spohrer, J., \& Kwan, S. K. (2009). Service science, management, engineering, and design (SSMED): An emerging discipline - outline \& references. International Journal of Information Systems in the Service Sector, 1, 1-31. https:/ / doi.org/10.4018/jisss.2009070101

Spohrer, J., \& Maglio, P. P. (2008). The emergence of service science: Toward systematic service innovations to accelerate co-creation of value. Production and Operation Management, 17, 1-9. https://doi.org/10.3401/poms.1080.0027

Spohrer, J., \& Maglio, P. P. (2010). Toward a Science of Service Systems. In Maglio, P., Kieliszewski, C., Spohrer, J. (eds), Handbook of Service Science. Service Science: Research and Innovations in the Service Economy (pp. 157-194). Springer, Boston, MA. https:/ / doi.org/10.1007/978-1-4419-1628-0_9

Spohrer, J., Maglio, P. P., Bailey, J., \& Gruhl, D. (2007). Steps toward a science of service systems. Computer, 40, 7177. https:// doi.org/10.1109/MC.2007.33

Teboul, J. (2006). Service Is Front Stage: Positioning Services for Value Advantage. Hampshire, England: Palgrave Macmillan. https:// doi.org/10.1057/9780230579477

Thompson, J., Bellanca, M., Owens, N., \& Lorenzo, G. (2012). Essential computer skills for college students. International Journal of Information Systems in the Service Sector, 4, 53-66. https://doi.org/10.4018/jisss.2012010104

Witell, L., Snyder, H., Gustafsson, A., Fombelle, P., \& Kristensson, P. (2016). Defining service innovation: A review and synthesis, Journal of Business Research, 69, 2863-2872. https://doi.org/10.1016/j.jbusres.2015.12.055

\section{http://www.ejmste.com}

